\title{
Editorial
}

\section{Seepage Mechanics in Rock Engineering}

\author{
Hailing Kong $\mathbb{D}$, ${ }^{1}$ Luzhen Wang $\mathbb{D},{ }^{2}$ and Hualei Zhang $\mathbb{D}^{3}$ \\ ${ }^{1}$ Yancheng Institution of Technology, Yancheng, China \\ ${ }^{2}$ University of Adelaide, Adelaide, Australia \\ ${ }^{3}$ Anhui University of Science and Technology, Huainan, China \\ Correspondence should be addressed to Hailing Kong; hailkong@126.com
}

Received 12 September 2018; Accepted 12 September 2018; Published 29 October 2018

Copyright ( 2018 Hailing Kong et al. This is an open access article distributed under the Creative Commons Attribution License, which permits unrestricted use, distribution, and reproduction in any medium, provided the original work is properly cited.

Seepage mechanics mainly studies the law of fluid movement in porous media, and its application is more and more extensive, which has become the theoretical basis of various engineering techniques [1]. Because porous media exist widely in nature and engineering materials and even in human beings, animals, and plants, the application scope of seepage mechanics can be roughly divided into different kinds of aspects, including underground seepage [2-4], engineering seepage [5-7], and biological seepage [8-10].

Seepage mechanics in rock engineering refers to both underground seepage and engineering seepage, describes the seepage of fluids in rocks and surface deposits, and studies the response of rock materials and rock masses under seepage. It covers wide applications in geological engineering [4], civil engineering [11], mining engineering [5, 6], environmental engineering [2], and water conservancy and hydropower engineering [7], especially underground fluid resources development projects, including coal, petroleum, natural gas, and coalbed methane [6]. In addition, it also involves farmland water conservancy, soil improvement (especially in coastal and salt-lake areas), and irrigation and drainage works [3], underground sewage treatment [2], reservoir water storage on the impact of the rockfill dam [7], etc.

Recently, a large number of remarkable advancements on challenging topics in rock seepage mechanics have been made in physical testing [12-14], numerical modelling [14] and theoretical studies [14], and engineering applications, which contain studies on the mechanism researches, the experimental researches, and the modelling and simulating researches on seepage problems in rock engineering, e.g., mining failure characteristics and water-inrush problems in workface, the water-conducting rule and seepage properties, the calculation of the effective water resisting rock beam, seepage behavior of dams under rainfall, and so on.

Karst collapse pillars (KCPs) are widely distributed in North China. Mining in coal mines with KCPs often accompanies with water-inrush accidents. In order to ensure the safe production of the coal industry, the main influencing factors and the mechanism of the accompanied water-inrush accidents need to be researched. KCP is the fractured rock mass with variable porous and fractured structures, which is formed by mixing various fractured rock blocks of different sizes and cemented together through muddy and siliceous thin layers on their surfaces under the self-gravity of collapse columns or ground pressure. Hence, the seepage properties are also the important factor of waterinrush besides mining. The paper "Experimental investigation on seepage stability of filling material of karst collapse pillar in mining engineering" authored by Bangyong Yu, Zhanqing Chen, and Jiangyu Wu talked about the impacts of variable initial porosity and cementing strength on the seepage properties of filling material. In order to study the seepage stability of filling materials of KCPs, three types of specimens cemented by clay, gypsum, and cement were tested by a self-designed and fabricated experimental system, which can offer high water pressure and abundant water flow rate. They researched the seepage properties under the initial porosity of $0.11,0.13,0.15$, and 0.17 , and discussed the change mechanism of seepage properties through the comparison between mass loss and mass gain. The results indicated that in some samples the permeability gradually increased up to the occurrence of seepage instability, while in some other samples the permeability gradually decreased 
and approached to a stable value, in which no seepage instability is observed. Initial porosity and cementing material significantly affected the water flow properties of the filling material. The samples with larger initial porosity have larger permeability. In samples using clay as the cementing material, seepage instability occurred soon, while it occurred after a period of time when gypsum was used as the cementing material; however, the permeability decreased with time and approached to a stable value in samples with cement.

Besides seepage instability, water-inrush in coal mines is mostly considered to result from mining. During mining, fractures are developed and expanded in the surrounding rock and connected with the fractured geological structure, then water flow channels are formed, and finally, waterinrush happens indirectly. The papers "A mechanical model of the overlying rock masses in undersea coal mining and a stress-seepage coupling numerical simulation," "Failure depth of a floor of a fully mechanized working face when passing a collapse column," and "Failure characteristics and confined permeability of an inclined coal seam floor in fluidsolid coupling" investigated the fracture characteristics of the roof and the floor of the workface under excavation and simulated the induced water-inrush accidents by FISH language and the FLAC ${ }^{3 \mathrm{D}}$ software.

The failure of the overlying rock due to mining may supply a water flow channel from the overlying aquifer to the workface, which perhaps would result in a roof water-inrush accident. Jie Fang, Lei Tian, Yanyan Cai, Zhiguo Cao, Jinhao Wen, and Zhijie Wen in the paper "A mechanical model of the overlying rock masses in undersea coal mining and a stress-seepage coupling numerical simulation" considered that the water inrush of a working face was the main hidden danger to the safe mining of underwater coal seams and pointed out that the developed water-flowing fractured zones in overlying strata were the main paths for water inrush when the accidents happened in working faces. They created an analysis model and the judgment method based on the Mohr-Coulomb criterion, taking the underwater mining in the Longkou mine as the engineering background, simulated the mining process of the underwater coal seam, and analyzed the initiation evolutionary characteristics and seepage laws of the fractured zones in the overlying strata during the advancing processes of the working face. They found that the open-off cut and mining working face were the key sections of the water inrush in the rock mass because the mining fractured zones which had been caused by the compression shear and tension shear were mainly concentrated in the overlying strata of the working face, which would form the possible water-inrush channels in underwater coal mining. Their numerical simulation results were validated through the practical engineering of field observations on the height of the water-flowing fractured zone.

The failure of the floor due to mining may supply a water flow channel from the aquifer in the floor to the workface, which perhaps would result in a water-inrush accident in the floor. When the fully mechanized coal mining workface passes through the collapse column, the risk of water inrush in the floor increases. The paper "Failure depth of a floor of a fully mechanized working face when passing a collapse column" by Jinlong Cai, Min Tu, and Wensong Xu discussed the stress change law of a collapse column and the failure depth of a coal seam floor before and after mining when the fully mechanized coal mining face passes through the collapse column. They established a numerical model of the 10-115 working face that passed the collapse column at a coal mine in Tuanbai and simulated the floor failure numerically to assess the damage. The simulation showed that the failure depth of the full floor was stabilized at $14.6 \mathrm{~m}$ and the maximum failure depth of the floor near the collapse column was $18.2 \mathrm{~m}$. Based on the Hoek-Brown criterion, the depth failure of the floor of the working face without structural defects was $14.6 \sim 14.7 \mathrm{~m}$ and was $16.8 \sim 17.8 \mathrm{~m}$ if the workface passed the collapse column. According to the water injection test, the maximum failure depth of the floor was $18 \mathrm{~m}$. From the results, the three derived values agreed well with one other.

Though the workface does not pass a collapse column, the failure characteristics and confined permeability of coal seam floor also play the important roles in the process of water-inrush in the floor. Jian Sun, Lianguo Wang, and Guangming Zhao established a 3D fluid-solid coupling numerical calculation model for an inclined seam mining above a confined aquifer in Taoyuan coal mine and simulated the mining failure depth of an inclined coal seam floor, conducting height of confined water, and the position of workface floor with easy water inrush during advancement of workface, which were presented in the paper "Failure characteristics and confined permeability of an inclined coal seam floor in fluid-solid coupling". It indicated that, during the advancement of the workface of the inclined coal seam, obvious equivalent stress concentration areas existed in the floor strata and the largest equivalent stress concentration area was located at the low region of workface floor. When the inclined coal seam workface advanced to about $80 \mathrm{~m}$, the depth of the floor plastic failure zone reached the maximum at approximately $15.0 \mathrm{~m}$, and the maximum failure depth was located at the low region of the workface floor. Before the inclined workface mining, original confined water conducting existed on the top interface of the confined aquifer. The conducting height of the confined water reached the maximum at about $11.0 \mathrm{~m}$ when the workface was pushed forward from an open-off cut at about $80 \mathrm{~m}$. Owing to the barrier effect of the "soft-hard-soft" compound waterresistant strata of the workface floor, pore water pressure and its seepage velocity in the floor strata were unchanged after the workface advanced to about $80 \mathrm{~m}$. After the strata parameters at the workface floor were changed, pore water pressure of the confined water could pass through the lower region of the inclined workface floor strata and break through the barrier of the "soft-hard-soft" compound waterresistant strata of the workface floor and into the mining workface, resulting in the inclined coal seam floor water inrush.

The strata in the floor of the workface in coal mines sometimes also have the barrier effect of resisting water from the aquifer. The deformation and stress distribution will 
determine whether the floor strata can work as the waterresisting strata, as well as the permeability variation law of the floor strata. The papers "Deformation and stress distribution of the effective water-resisting rock beam under water-rock coupling action inside the panel floor" and "The assessment and evolution of water-conducting rules under the influence of mining-induced stress" investigated the floor's resisting effect by the calculation of the deformation and stress in the floor and exploration of the rules of permeability variations during rock deformation under excavation, respectively.

Due to the excavation, the floor of the workface deformed and fractured, and the stress in the floor also redistributed, which all affected the resisting effect of the floor strata. Baojie Fu, Hualei Zhang, Min Tu, and Xiangyang Zhang took the stability of the panel floor above confined water as the key to determining the water inrush from the panel floor. They established a mechanics analysis model of floor water-resisting rock beam to study the trends of deflection and internal stress in the effective water-resisting rock beam under the combined action of mining stress and water pressure based on the characteristics of "lower three zones" of the panel floor, the principle of virtual work, and the energy functional variation conditions in the paper "Deformation and stress distribution of the effective waterresisting rock beam under water-rock coupling action inside the panel floor". According to the geological and mining conditions of the A3 coal seam in the Panxie Mining Area of Huainan Mining Group, they analyzed three factors influencing on the stability of floor rock beam, including elastic modulus, coefficient of viscosity, and water pressures. The results showed that the elastic modulus played the most important role in the deformation of the rock beam. To improve the mechanical properties of the rock beam, it was necessary to reinforce the floor to improve the ability for resisting floor deformation and to increase the coefficient of rock viscosity in the water damage zone and reduce the speeds of loading and deformation in the whole rock beam. They found hydrophobic decompression could also effectively reduce the stress on the boundary of the rock beam and enhance the stability of the panel floor above confined water.

The rules of permeability variations during rock deformation and fracturing on the seam floor are important to study the mechanism of water inrush in the floor, as well as the responses to characteristics of the macromechanical environment, such as mine ground pressure, engineering geology, and fluid mechanics. Feisheng Feng, Suping Peng, Wenfeng Du, Yunlan He, and Shan Chong have done some research studies on "The assessment and evolution of waterconducting rules under the influence of mining-induced stress." They established a mechanical model for the seam floor above the confined water through the analysis of bearing pressure changes in the process of exploiting the working face and calculated and obtained the vertical, horizontal, and shear stresses and the corresponding variation curve of the rock stratum $5 \mathrm{~m}$ below the floor, covering the entire process from a position $120 \mathrm{~m}$ away from the working face to a position $280 \mathrm{~m}$ behind it using the graphic data-processing software Mathcad. They tested the permeability coefficients of different lithologies in the laboratory, simulated the actual stress and the dynamic stress environment of the rocks to study the permeability characteristics, and analyzed the permeability coefficient variations for a rock stratum $5 \mathrm{~m}$ below the floor in the mining process. In accordance with the permeability variation law of the floor of the working face, they divided the seam floor into six areas, including the compression and expansion zone, the bed separation and expansion zone, the pressure relief zone, the compression zone, the stable recovery zone, and the stability zone, to express the water-resisting performance of the floor more objectively.

All the above talk about the seepage problems in mining; actually, seepage also occurs in other rock engineering, for example, water conservancy and hydropower engineering.

Due to the climate characteristics of East Asia, more than $60 \%$ of annual rainfall in Korea is concentrated during the monsoon season from June to August, reservoir water level sharply rises during this period, and the rockfill dams are exposed to various types of damage related to seepage problems, such as soil erosion and piping. Therefore, the consideration for any rainfall effect on the seepage behavior of earth dams is very important. Jong-Wook Lee, Jiseong Kim, and Gi-Chun Kang researched "Seepage behavior of earth dams considering rainfall effects." They filtered out rainfall from the measured seepage rates to evaluate the effects of rainfall using a digital filtering method for two large rockfill dams, Dams A and B, the seepage behavior in which was estimated as a steady-state condition. It was proven that the application of a digital filter which filters out rainfallinduced infiltration into a downstream shell from a measured seepage flow would make analyzing the seepage behavior of dams more effective. The results showed that the seepage rate of Dam A was not significantly affected by rainfall because the seepage water was collected inside the dam body and transferred to a V-notch weir located downstream from the dam through a steel pipe, while the seepage rate at Dam B was greatly influenced by rainfall in the rainy season. They also estimated the permeability of the core zones for Dams A and B by a simplified method, which was $8.5 \times 10^{-5} \mathrm{~cm} / \mathrm{s}$ and $2.7 \times 10^{-5} \mathrm{~cm} / \mathrm{s}$, respectively.

Seepage mechanics in rock engineering include but not limited to the above aspects. Some of the latest and most challenging research topics in rock seepage mechanics also include the seepage field distribution and propagation and the corresponding dynamic responses and failure of rock materials and rock masses in the underground environments featuring high temperature, high in situ stress, and other physicochemical conditions, seepage properties variation and particle migration behavior in fractured rock mass, and even the multiphase seepage behavior in rock engineering. There are still more unknowns in this field waiting to be explored and discovered in the future.

\section{Conflicts of Interest}

The authors declare that there are no conflicts of interest regarding the publication of this article. 


\section{Acknowledgments}

We would like to thank the colleagues who have paid attention to this topic, the authors who have submitted manuscripts to this special issue because of their excellent works, and the referees who have put in hard work and their valuable time to review each paper in a professional way. We also would like to thank all the editors for their contribution in reviewing and assigning reviews for the submitted manuscripts.

Hailing Kong

Luzhen Wang

Hualei Zhang
[12] L. Wang and H. Kong, "Variation characteristics of mass-loss rate in dynamic seepage system of the broken rocks," Geofluids, vol. 2018, Article ID 7137601, 17 pages, 2018.

[13] L. Wang, Z. Chen, and H. Kong, "An experimental investigation for seepage-induced instability of confined broken mudstones with consideration of mass loss," Geofluids, vol. 2017, Article ID 3057910, 12 pages, 2017.

[14] L. Wang and H. Kong, Accelerated Experimental Study on Permeability for Fractured Rock Accompanying with Mass Loss, The Science Publishing Company, Beijing, China, 2017.

\section{References}

[1] X. Miao, W. Liu, and Z. Chen, Seepage Theory of Mining Rock Mass, The Science Publishing Company, Beijing, China, 2004.

[2] T. Sun, Y. He, Z. Ou et al., "Treatment of domestic wastewater by an underground capillary seepage system," Ecological Engineering, vol. 11, no. 1-4, pp. 111-119, 1998.

[3] D. L. Hughson and F. T. Dodge, "The effect of cavity wall irregularities on seepage exclusion from horizontal cylindrical underground openings," Journal of Hydrology, vol. 228, no. 34, pp. 206-214, 2000.

[4] T. Yang, P. Wang, H. Liu, T. Xu, Q. Yu, and W. Shi, "Deformational behavior of underground opening using a stress-seepage coupled model considering anisotropic characteristics," Arabian Journal of Geosciences, vol. 8, no. 9, pp. 6635-6642, 2015.

[5] S. Finsterle and R. C. Trautz, "Numerical modeling of seepage into underground openings," Mining Engineering, vol. 53, no. 9, pp. 52-56, 2001.

[6] L. Yang, "Numerical simulation on three-dimensional nonlinear and unstable seepage of fluid in underground coal gasification," Fuel Processing Technology, vol. 84, no. 1-3, pp. 79-93, 2003.

[7] C. Yi, B. Wang, M. Jin, and Z. Guo, "Two-dimensional simulation of underground seepage in a dangerous piping zone of the jingjiang great levee, the middle reach of the Yangtze river," Quarterly Journal of Engineering Geology and Hydrogeology, vol. 40, no. 1, pp. 85-92, 2007.

[8] K. K. L. Wong, "Three-dimensional discrete element method for the prediction of protoplasmic seepage through membrane in a biological cell," Journal of Biomechanics, vol. 65, pp. 115-124, 2017.

[9] B. S. Gardiner, G. R. Joldes, K. K. L. Wong, C. W. Tan, and D. W. Smith, "Controlling seepage in discrete particle simulations of biological systems," Computer Methods in Biomechanics and Biomedical Engineering, vol. 19, no. 11, pp. 1160-1170, 2016.

[10] S. Dinarvand, "Viscous flow through slowly expanding or contracting porous walls with low seepage Reynolds number: a model for transport of biological fluids through vessels," Computer Methods in Biomechanics and Biomedical Engineering, vol. 14, no. 10, pp. 853-862, 2011.

[11] M. G. Sweetenham, R. M. Maxwell, and P. M. Santi, "Assessing the timing and magnitude of precipitation-induced seepage into tunnels bored through fractured rock," Tunnelling and Underground Space Technology, vol. 65, pp. 62-75, 2017. 


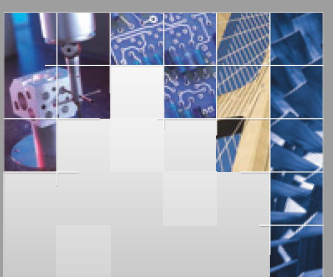

\section{Enfincering}
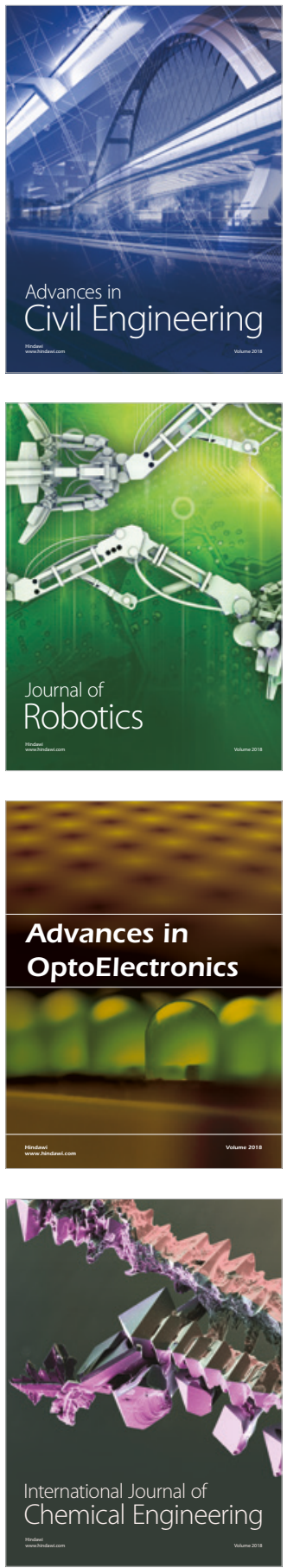

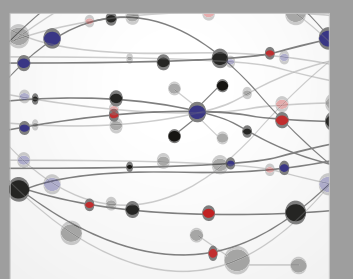

\section{Rotating \\ Machinery}

The Scientific World Journal

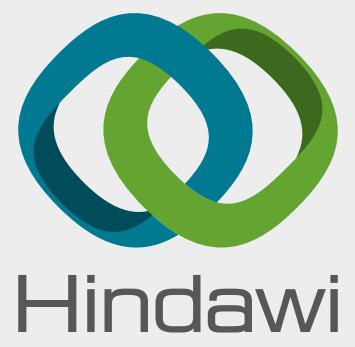

Submit your manuscripts at

www.hindawi.com
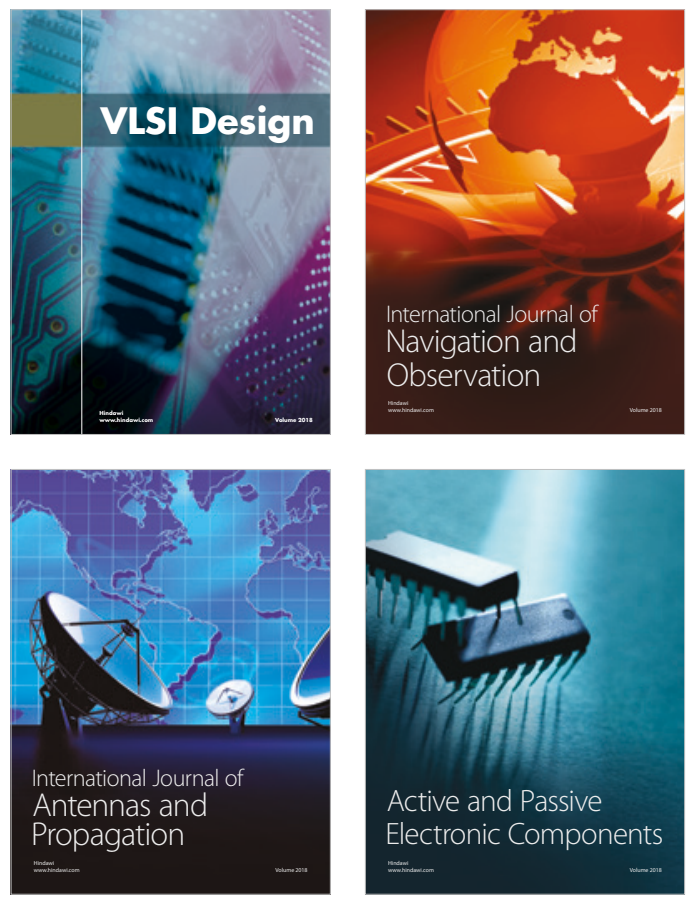
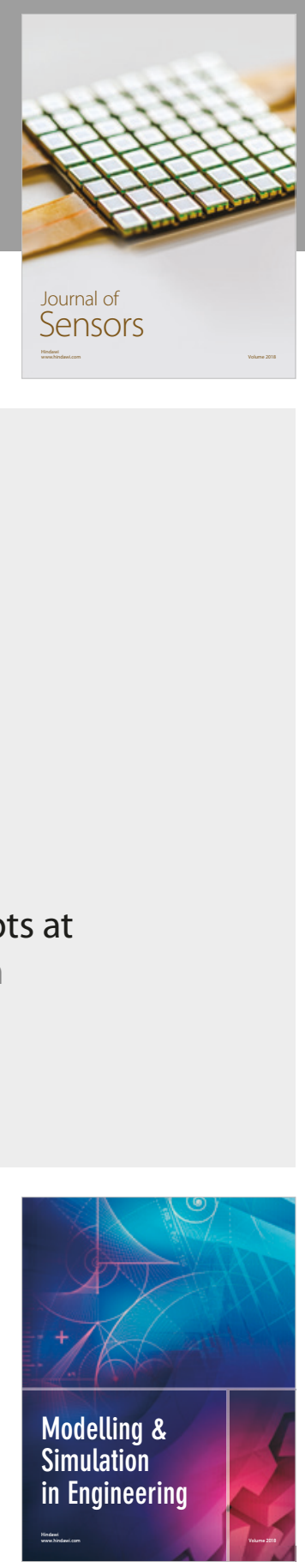

\section{Advances \\ Multimedia}
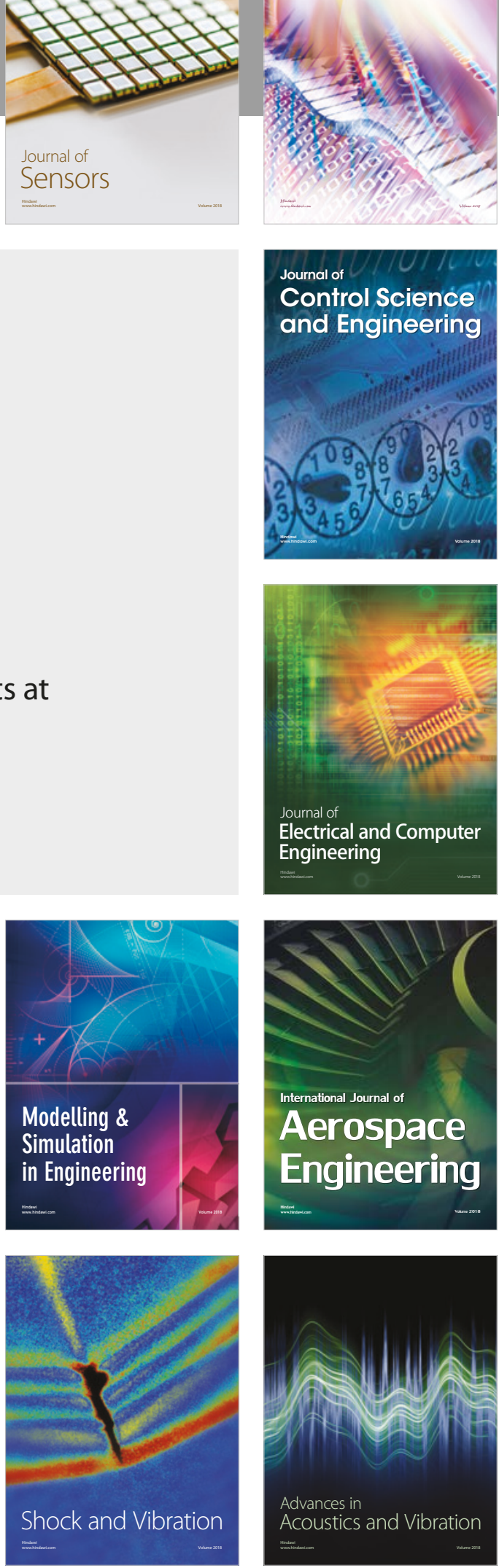